\title{
PERAN PEMERINTAH DESA DALAM MENANGGULANGI KENAKALAN REMAJA DI DESA BALAHU KECAMATAN TIBAWA KABUPATEN GORONTALO
}

\author{
Oleh:
}

Iin Lapamusu, Telly D. Wua, N. F. Kaunang

Email: telly_wua@unima.ac.id

\begin{abstract}
ABSTRAK
Masa remaja merupakan masa dimana seorang individu mengalami peralihan dari satu tahap ke tahap yang berikutnya dan mengalami perubahan baik emosi, tubuh, minat, pola perilaku, dan juga penuh dengan masalah-masalah. Remaja merupakan masa peralihan antara anak-anak dan dewasa, Remaja mulai mencoba-coba bertindak dan berperilaku seperti orang dewasa, misalnya: merokok, minum-minuman keras, menggunaka obat-obatan, dan lainlain.Tujuan penelitian ini adalah untuk mengetahui sejauh mana kepedulian pemerintah desa dalam menanggulagi kenakalan remaja, dana apa saja yang menjadi faktor terjadinya kenakalan remaja de desa Balahu Kecamatan Tibawa Kabupaten Gorontalo. Metode yang digunakana adalah metode deskriptif kualitatif yaitu penulis menggambarkan secara jelas dengan data yang diperoleh dilapangan.Hasil penelitian yang diperoleh melalui wawancara dengan para informan yang ada menunjukkan bahwa penyebab terjadinya kenalakan remaja di Desa Balahu yaitu: kurangnya perhatian Pemerintah desa, karena pemerintah desa lebih mengutamakan pembangunan infrasturuktur ketimbang pembangunan pembentukkan karakter pemuda di masa pertumbuhannya. Dari hasil penelitian dapat disimpulkan bahwa kurangnya perhatian pemerintah desa terhadap pembentukan karakter generasi muda, karena pemerintah desa lebih mementingkan permbangunan infrastruktur desa.
\end{abstract}

Kata Kunci: Peran, Pemerintah Desa, Kenakalan Remaja 


\section{PENDAHULUAN}

Menurut Pasal 18 Ayat 1 UndangUndang Dasar 1945 menegaskan bahwa "Negara Kesatuan Republik Indonesia di bagi atas daerah-daerah provinsi, dan daerah provinsi itu dibagi atas kabupaten dan kota, yang diatur dengan "undang-undang". Jadi secara implicit menurut ketentuan ini sebenarnya pemerintahan desa adalah bagian pemerintahan daerah.

Dalam konteks Undang-Undang Nomor 32 Tahun 2004 tentang Pemerintah Daerah, desa dibedakan dengan kelurahan. Desa adalah kesatuan masyarakat hukum yang memiliki batas-batas wilayah yang berwenang untuk mengatur dan mengurus kepentingan masyarakat setempat bersadarkan asal-usul dan adat istiadat setempat yang diakui negara, sedangkan kelurahan adalah satuan administrasi pemerintahan di bawah kecamatan yang merupakan wilayah pelayanan administrasi dari kabupaten/kota.

Di zaman moderen seperti sekarang ini, banyak berbagai macam fasilitas pendukung bagi masyarakat terutama bagi para kaum remaja. Fasilitas tersebut dari zaman ke zaman semakin berkembang misalnya laptop dan handphone. Karena kecanggihan itulah sisi negatifnya yakni remaja menjadi malas dan cenderung melakukan hal yang negatif. Peran orang tua terhadap anaknya sangat berpengaruh, setiap orang tua hendaknya selalu memperhatikan anak agar anak dapat bertindak secara baik. Akan tetapi karena kesibukan orang tua, sehingga beberapa orang tua tidak memperhatikan anaknya. Apalagi pergaulan anak sekarang ini semakin bebas. Masalah kenakalan remaja cenderung terjadi di daerah kota-kota besar namun tidak menutup kemungkinan dapat terjadi di desa.

Peran Pemerintah Desa dalam menjalankan roda pemerintahan, pembangunan dan kemasyarakatan menjadi penentu keberhasilan, hal ini disebabkan pemerintah desa merupakan pimpinan penyelenggaraan pemerintahan otonomi desa yang dipilih langsung oleh warganya.
Pemerintah desa yang dimaksud disini adalah Kepala Desa dan Perangkatnya, sesuai dengan Pasal 12 ayat 1 Peraturan Pemerintah Nomor 72 Tahun 2005 Tentang Desa. Dalam melaksanakan urusan kemasyarakatan, pemerintah desa dituntut lebih tanggap menyikapi dan menyelesaikan konflik yang terjadi ditengah-tengah warganya, pemerintah desa mampu bersifat netral, dengan mengedepankan prinsip kebenaran, tanpa harus memihak.

Masa remaja merupakan masa dimana seorang individu mengalami peralihan dari satu tahap ke tahap yang berikutnya dan mengalami perubahan baik emosi, tubuh, minat, pola perilaku, dan juga penuh dengan masalah-masalah. Remaja merupakan masa peralihan antara anak-anak dan dewasa, pada masa ini ada juga keraguan terhadap peran yang akan dilakukan. Remaja bukan lagi seorang anak dan juga bukan orang dewasa.

Remaja mulai mencoba-coba bertindak dan berperilaku seperti orang dewasa, misalnya: merokok, minum-minuman keras, menggunaka obat-obatan, dan lain-lain. Tindakan ini tidak sesuai dengan norma atau aturan yang berlaku di masyarakat (juveline delinquency). Dalam kehidupan bermasyarakat sekarang ini masalah kenakalan remaja merupakan hal yang lazim. Ada banyak masalah kenakalan remaja yang ditemukan, misalnya: tawuran, pertengkaran antara orang tua dengan anak, pesta miras, narkoba, dan lain-lain.

Dari tahun ke tahun kenakalan remaja di Indonesia semakin bertambah dan para remaja semakin menjadi-jadi dalam kehidupan pergaulannya sehingga menganggu ketentraman baik dilingkungan keluarga maupun masyarakat. Sebagaimana kita ketahui bahwa pada akhir-akhir ini tindak pidana yang dilakukan oleh anak atau remaja semakin meningkat, meresahkan masyarakat dan menyebabkan terjadinya kejahatan-kejahatan yang dilakukan oleh anak atau remaja tersebut.

Hal ini dapat kita ketahui melalui berbagai media yang antara lain: radio, surat kabar, televisi, majalah, serta media cetak 
lainnya dan bahkan dari internet yang memberi kita informasi mengenai masalah kejahatan yang dilakukan oleh anak atau remaj tersebut. Remaja sebagai bagian dari generasi mudah adalah merupakan kaderkader penerus perjuangan bangsa dimana nantinya akan melanjutkan pembangunan nasional menuju cita-cita masyarakat yang adil dan makmur di masa depan nanti. Eksistensi remaja sebagai penerus bangsa sangat diharapkan dalam memajukan pembagunan disegala bidang.

Hampir di setiap tempat kita banyak menyaksikan kenakalan remaja baik di kotakota besar sehingga di daerah-daerah terpencil atai di pedesaan dan masingmasing tempat berbeda faktor penyebabnya. Kalau di perkotaan kanakalan remaja lebih di sebabkan leh seiring kemajuan yang terjadi di kota di mana segala fasilitas pendukungnya tersedia seperti tempattempat hiburan malam, pengaruh pergaulan bergaya modern yang tidak lagi mengenal ke arifan local dan lain sebagainya.

Seperti contoh di Desa Balahu Kec. Tibawa Kab. Gorontalo, dimana kenakalan remaja sering terjadi di desa tersebut diakibatkan hampir rata-rata para orang tua memiliki tingkat pendidikan rendah dan kurangnya perhatian pemerintah terhadap generasi penerus yang akan menerima tongkat estapet untuk melanjutkan kelangsungan hidup masyarakat di desa itu sendiri, sesuatu yang sulit di hindari adalah ketika anak remaja yang masih memiliki usia sekolah terpaksa putus sekolah karena di minta oleh orang tuanya membantu bekerja di sawah atau di lading sekaligus menjadi buruh tani yang nantinya akan mendapatkan upah sama dengan yang di terima oleh orang tuanya, maka disini orang tua harus mampu pengawasi dan pengarahkan anak remajanya.

Akan tetapi yang terjadi adalah orang tua lalai melakukan bimbingan terhadap anak remajanya dalam menggunakan uang atau upah yang dia peroleh, kalau yang di peroleh orang tuanya di gunakan untuk memenuhi kebutuhan keluarga maka remaja di gunakan untuk berfoya-foya dengan teman-temannya yang memiliki profesi yang sama, dari beberapa remaja berkumpul mereka berjoin atau istilah lainnya di desa itu kong-kong, membeli minuman keras sebanyak mungkin dan mereka minum sampai mabuk.

Peran pemerintah desa juga kurang dalam membuat peraturan desa atau yang di kenal dengan PERDES, padahal di desa ada mitra pemerintah desa yang disebut Badan Perwakilan Desa (BPD) yang memiliki fungsi membantu pemerintah desa dalam angka membuat peraturan desa. Pemerintah desa dan badan perwakilan desa (BPD) dapat bersama-sama membuat peraturan yang mengatur tentang peredaran dan penjualan minuman keras. Dalam penegakkan perdesnya pemerintah desa bekerja sama dengan pihak keamanan desa apakah itu satgas desa atau hansip untuk sama-sama menjaga keamanan serta menimalisir dan meredam kekacauan di desa yang di akibatkan oleh kenakalan remaja agar kehidupan yang harmonis dan damai dapat di rasakan oleh seluruh penduduk atau masyarakat di desa itu sendiri.

Berdasarkan latar belakang masalah diatas, maka penulis ingin melakukan penelitian lebih lanjut mengenai "Peran Pemerintah Desa dalam menanggulangi kenakalan remaja studi kasus di Desa Balahu Kec. Tibawa Kab. Gorontalo.

Berdasarkan batasan masalah di atas, maka rumusan masalah sebagai berikut: Bagaimana peran pemerintah desa dalam menanggulangi kenakalan remaja dan faktor apa yang mempengaruhi Kenakalan Remaja di Desa Balahu Kecamatan Tibawa Kabupaten Gorontalo.

\section{METODE PENELITIAN}

Metode yang di gunakan dalam penelitian ini adalah metode kualitatif. Metode kualitatif adalah salah satu prosedur penelitian yang menghasilkan data deskriptif berupa ucapan atau tulisan dan perilaku dari orang-orang (Subjek) itu sendiri. (Bogdan dan Taylor 1975). 
Jadi penelitian menggunakan metode kualitatif diharapkan mampu memberikan gambaran tentang Peran Pemerintah Desa dalam Menanggulangi Kenakan Remaja (Studi kasus di Desa Balahu Kec. Tibawa Kab. Gorontalo) dengan tepat dan berkualitas. Penelitian ini akan dilaksanakan di Kabupaten Gorontalo di Desa Balahu Kecamatan Tibawa. Sumber data dalam penelitian adalah kepala desa, kepala lingukngan, tokoh agama, keluarga dan remaja di desa Balahu Kecamatan Tibawa Kabupaten Gorontalo.

Agar diperoleh data yang valid dalam penelitian ini perlu ditentukan teknik-teknik pengumpulan data yang sesuai. Dalam hal ini peneliti menggunakan teknik-teknik observasi dan wawancara. Dalam penelitian ini teknik analisis data yang digunakan adalah analisi data interaktif yang disampaikan oleh Huberman dan Miles (1992:20), di mana terdapat tiga hal utama dalam analisis interaktif yakni: reduksi data, penyajian data, dan penarikan kesimpulan/verifikasi sebagai suatu yang jalin menjalin pada saat sebelum, selama dan sesudah pengumpulan data dalam bentuk yang sejajar, untuk membangun wawasan umum di sebut "analisis".

\section{PEMBAHASAN HASIL PENELITIAN}

Sesuai dengan apa yang diteliti oleh peneliti tentang peran pemerintah desa dalam menanggulangi kenakalan remaja di desa Balahu kecamatan Tibawa kabupaten Gorontalo masih dikatakan bahwa kurangnya perhatian pemerintah akan mempentukan karakter dari anak remaja di desa Balahu dipengaruhi oleh beberapa faktor sehingga peneliti mendeskripsikan faktor-faktor ini menjadi beberapa bagian.

Meskipun hanya sekian beberapa anak-anak remaja dan masyarakat desa Balahu yang menjadi responden dalam penelitian ini namun peneliti berusaha utnuk melakukan penelitian subjektif di tengah masyarakat di desa Balahu.

Melalui hasil wawancara dan jawabanjawaban oleh responden maka dapat bahwa
Peran Pemerintah Desa dalam menanggulangi kenakalan remaja di Desa Balahu tidak begitu baik. Sehingga hasil dari wawancara, peneliti menemukan ada beberapa faktor yang mempengaruhi Peran Pemerintah desa dalam menanggulangi kenakalan remaja di Desa Balahu dikatakan kurang begitu baik dan perlu dibahas antara lain.

\section{Kurangnya Keterlibatan Pemerintah Desa Dalam Penyaluran Bakat Dan Hobi Bagi Generasi Muda}

Pemerintah Desa adalah penyelanggaraan urusan pemerintah oleh pemerintah Desa dan Badan Permusyawaratan Desa dalam mengatur dan mengurus kepentingan masyarakat setempat berdasarkan asal-usul dan adat-istiadat setempat yang diakui dihormati dalam sistem Pemerintah Negara Kesatuan Republik Indonesia. (Undang-Undang Nomor 6 tahun 2014).

Generasi muda adalah pemegang tongkat estapet keberlangsungan kehidupan bermasyarakat. Maka setiap komponen masyarakat harus bekerja sama untuk mampu menciptakan kehidupan masyarakat yang memberi arahan, bimbingan, bagi seluruh aktivitas kepemudaan di desa. Peran ini adalah bagian pemerintah desa selaku pemegang kekuasaan dan memiliki kewenangan terhadap kehidupan generasi muda.

Generasi muda adalah bagian yang terpenting dalam kemajuan kehidupan dalam masyarakat. Dalam filsafat Arab mengatakan: "pemuda sekarang adalah pemimpin dimasa yang akan datang". Maka pencegahan terhadap tindakan kriminalitas yang terjadi ditengah-tengah kehidupan remaja menjadi hal yang terpenting dalam wujud membangun masyarakat yang aman, tentram dan damai. Prestasi dan keberhasilan generasi muda adalah salah satu bagian yang menjadi kebanggaan bagi suatu kehidupan masyarakat, dan sebaliknya kebobrokan mental dan akhlak generasi muda adalah cermin dari pada kegagalan pemerintahan 
dalam mewujudkan terciptanya kehidupan generasi muda yang gemilang.

\section{Kurangnya Perhatian Pemerintah Desa Melakukan Sweeping Tehadap Miras di Tempat-tempat yang Memberi Peluang Terhapat Kenalanan Remaja}

Kenakalan remaja adalah perbuatan anti-sosial yang dilakukan oleh anak remaja yang bilamana dilakukan orang dewasa dikualifikasikan sebagai tindakan kejahatan. Menurut Faud Hasan (Sudarsono, 2008:11).

Dengan ini, maka dengan mencegah timbulnya kenakalan remaja yaitu menundukan kembali cara melihata permasalahan pada titik yang sebenarnya, yakni melibatkan semua aparat desa untuk melakukan sweeping minuman keras di setiap warung terdekat, karena hal tersebut merupakan salah satu unsur yang baik untuk menanggulangi kenakalan remaja kemudian menfungsikan kembali keluaraga sebagai agar suatu forum pendidikan, pembinaan ahlak, dimana sebagai para orang tua seharusnya merekalah yang dekat dalam perkembangan kehidupan remaja.

Banyak contoh kasus yang ditemui peneliti, dimana banyak masyarakat usia remaja hingga larut malam duduk dipinggiran desa, di tempat-tempat keramaian, di warung-warung terdekat, hal tersebut seharusnya berada dalam wewenang pemerintah desa untuk memantau segala aktivitas-aktivitas yang terjadi di desa tersebut.

Contoh kasus yang peneliti temui adalah kasus pencurian ternak di desa Balahu, tak jarang kasus pelakunya ini adalah anak-anak remaja.

Jadi bisa dikatakan seharusnya pemerintah desa lebih ketat dan cepat dalam melihat produk apa saja yang dijual di warung-warung yang sering muncul kenakalan remaja.

\section{Perhatian Instansi Pemerintah Dalam Hal Pihak Sekolah Yang Ada Di Desa Balahu}

Menurut Undang- Undang No. 20 tahun 2003 tentang Sistem Pendidikan
Nasional (Sisdiknas) telah menegaskan bahwa pendidikan Nasional berfungsi untuk mengembangkan kemampuan dan bentuk watak serta peradaban bangsa yang bermartabat dalam rangka mencerdaskan kehidupan bangsa, bertujuan untuk perkembangan potensi peserta didik agar menjadi manusia yang beriman dan bertaqwa kepada Tuhan Yang Maha Esa, berahlak mulia, sehat, berilmu, cakap, kreatif, mandiri dan menjadi warga negara yang demokratis serta bertanggung jawab.

Dalam Undang-Undang No. 20 tahun 2003 tentang Sistem Pendidikan Nasional berusaha untuk membentuk manusia menjadi manusia yang bertaqwa dan berahlak mulia tampaknya yang dilakukan lembaga pendidikan dan instansi Pembina lain belum sepenuhnya mengarahkan dan mencurahkan secara keseluruhan dari pada upaya tujuan Pendidikan Nasional. Lebih khususnya kita seharunya memantau sekolah yang mempunyai keterkaitan khusus generasi muda yang ada di desa Balahu seperti guru PPKn seharusnya pelajaran PPKn perlu diperhatikan secara khusus di sekolah-sekolah yang ada di desa Balahu, karena pelajara PPKn adalah mata pelajaran sangat berpengaruh pada pembinaaan dan pembentukan karakter dari generasi muda yang ada di desa Balahu.

Jadi instansi pendidikan sangat berpengaruh terhadap tumbuh kembangkan generasi muda di seluruh Indonesia sampai ke polosok desa terlebih kusus dalam hal ini desa Balahu, karena melalui instantsi pendidikan pada generasi muda yang terlannjur terpengaruh akan tindakantindakan negatif atau melanggar norma sedikit demi sedikit akan mengubah cara hidup mereka yang kurang baik.

\section{KESIMPULAN DAN SARAN Kesimpulan}

Berdasarkan hasil analisis data dan pembahasan, maka dapat ditarik kesimpulan sebagai berikut:

1. Pemerintah desa Balahu kurangnya memberi perhatian kepada perkembangan 
remaja sehingga mereka beraktifitas tanpa pengawasan dari pemerintah setempat. Kurangnya perhatian pemerintah terhadap aktifitas-aktifis remaja sehingga munculnya perilakuperilaku buruk dikalangan remaja sering nongkrong bersama teman-teman kemudian melakukankegiatan-kegiatan seperti, mengkonsusmsi miras, merokok, mencuri dan lain-lain

2. Lemahnya pengawasan terhadap warungwarung yang menjual produk yang membahayakan terhadap perkembangan mental generasi muda seperti mengkonsumsi minuman keras dan bahan lainnya yang menimbulkan efek buruk bagi generasi muda yang ada di desa Balahu.

3. Pemerintah desa kurang memberikan peraturan-peraturan yang intinya bisa membawa perkembangan generasi muda kearah yang positif, karena perilaku generasi muda di desa Balahu bisa dikatakan cenderung mengarah pada arah yang negatif, sehingga masa depan generasi muda di desa Balahu intinya akan mengarah ke arah yang negatif.

\section{Saran}

1. Masalah kenakalan remaja seharusnya perlu mendapatkan perhatian pemerintah bahwa kenakalan remaja tidak hanya merupakan masalah dalam lingkungan keluaraga akan tetapi menjadi perhatian khusus bagi pemerintah, oleh sebab itu perlu adanya tindakan dari pemerintah untuk menyelesaikan persoalan kenakalan remaja agar tercipt rasa aman dan tentram bagi masyarakat serta kehidupan generasi yang menuju kea rah yang lebih baik.

2. Untuk menanggulangi kenekalan remaja di desa Balahu perlu adanya tindakan nyata dari pihak pemerintah desa untuk menghentikan peredaran minuman keras di warung-warung terdekat, karena selama ini yang sering menjadi pemicu suatu konflik dan tindakan yang berhubungan dengan kenakalan remaja yaitu minuman keras.

3. Pemerintah desa sebaiknya memantau perkembangan remaja dan memberikan kebijakan untuk mengembangkan minat dan hobi mereka, sehingga perekembangan dan kemajuan desa tidak hanya dilihat dari segi fisiknya tetapi juga perkembangan dan kemajuan desa juga terlihat pada masyarakat yang ada di desa Balahu melalui prestasi yang nantinya mereka raih.

\section{DAFTAR PUSTAKA}

Kartono, K. 1986. Patologi Sosial: Kenakalan Remaja. Jakarta: Rajawali.

Yudrik, J. 2011. Psikologi Perkembangan. Jakarta: Penerbit Kencana.

Hanif, N. 2011. Pertembuhan \& Penyelenggaraan Pemerintahan Desa. Jakarta: Penerbit Erlangga

Rusdianto, S. 2013. Hukum Otonomi Daerah. Bandung: Penerbit Refika Aditama.

Djamaluddin, D. 2015. Mendidik Remaja Nakal. Yogyakarta: Penertbit Semesta Hikmah.

Sarwono, S. 2016. Psikologi Remaja. Jakarta: Penerbit PT RajaGrafindo Persada.

Ahmadi, R. 2016. Metode Penelitian Kualitatif. Yogyakarta: Penerbit Ar-ruzz Media.

Herdiansyah, H. 2015. Wawancara Observasi dan Focus Grounps. Jakarta: PT Rajagrafindo Persada.

Undang- Undang no 23 Tahun 2014 tentang Pemerintahan Daerah

Undang-undang No 6 Tahun 2014 Tentang Desa Peraturan pemerintah No.72 Tahun 2005 tentang Desa

https://media.neliti.com/media/publications/1061-ID-peran-pemerintah-desa-dalammenyelesaikan-pertikaian-antar-warga-desa-basaan-kec.pdf

https://paxdhe-mboxdhe.blogspot.co.id/2014/03/remaja-dan-kenakalan-remaja.html http://ewintribengkulu.blogspot.co.id/2013/04/pengertian-kenakalan-remaja.html?=1 http://repository.uksw.edu/bitstream/123456789/7350/2/T1_132008043_BAB\%20II.pdf http://fadzrianto.blogspot.co.id/2016/11/pengertian-menurut-para- ahli.html 